\title{
Decreased Granulocyte-Macrophage Colony- Stimulating Factor Production by Human Neonatal Blood Mononuclear Cells and T Cells
}

\author{
B. KEITH ENGLISH, WILLIAM P. HAMMOND, DAVID B. LEWIS, CHRISTOPHER B. BROWN, \\ AND CHRISTOPHER B. WILSON
}

Department of Pediatrics [B.K.E., D.B.L., C.B.W.], Department of Medicine [W.P.H., C.B.B.] and Department of Immunology [C.B.W.], University of Washington, Seattle, Washington 98105, and the Department of Pediatrics

[B.K.E.], University of Tennessee, Memphis, Tennessee 38103

\begin{abstract}
Impaired production and delivery of neutrophils to the site of infection have been implicated in the increased susceptibility of the neonate to infection. Because granulocyte-macrophage colony-stimulating factor (GMCSF) and granulocyte colony-stimulating factor (G-CSF) play critical roles in the production of neutrophils from marrow precursors, we assessed the ability of leukocytes from neonates and adults to produce GM-CSF, G-CSF, and, for comparison, macrophage colony-stimulating factor (M-CSF) after stimulation with concanavalin $\mathrm{A} \pm$ phorbol myristate acetate [blood mononuclear cells (MC) and T lymphocytes] or lipopolysaccharide (monocytes). MC and monocytes from adult and neonatal subjects produced mRNA for GM-CSF, G-CSF, and M-CSF, whereas T cells produced only GM-CSF mRNA. Neonatal MC and T cells accumulated only $\sim \mathbf{3 0} \%$ as much GM-CSF mRNA as did adult $M C$ and $T$ cells. In contrast, the accumulation of GM-CSF mRNA by neonatal and adult monocytes was similar. Neonatal MC also accumulated similar amounts of G-CSF mRNA and somewhat more M-CSF mRNA than did adult $\mathrm{MC}$; results with monocytes were similar to those with MC. Results of colony-stimulating activity bioassays on supernatants from neonatal and adult MC stimulated with concanavalin A paralleled the mRNA results. Although the overall number of colonies generated using neonatal and adult supernatants was similar, neonatal MC supernatants generated significantly more $(p<0.05)$ monocyte-containing colonies $(72 \pm 19$ versus $46 \pm 11)$, significantly fewer $(p<0.05)$ eosinophil-containing colonies $(7 \pm 6$ versus $23 \pm 13)$, and similar numbers of granulocyte-containing colonies $(59 \pm 23$ versus $63 \pm 11)$ compared with adult MC supernatants. Because GM-CSF is a major determinant of eosinophil production in these assays, these data suggested diminished amounts of GMCSF in the neonatal culture supernatants. Similarly, GMCSF concentrations in neonatal $\mathrm{MC}$ and $\mathrm{T}$ cell culture supernatants averaged 40 to $50 \%$ of the concentrations in adult culture supernatants as determined by ELISA $(p<$ 0.01 ). Whether the modestly diminished GM-CSF production by neonatal $T$ cells contributes to the observed deficiency of granulocyte production in neonates, which occurs when demand is increased in response to infection, remains to be determined. (Pediatr Res 31:211-216, 1992)
\end{abstract}

Received April 26, 1991; accepted October 9, 1991.

Reprint requests: B. Keith English, M.D., Department of Biochemistry, St. Jude's Children's Research Hospital, 332 North Lauderdale, Memphis, TN 38105. Supported in part by Grants HD18184, HL39157, and F32 HD06948 from the National Institutes of Health.

\author{
Abbreviations \\ CSF, colony-stimulating factor \\ GM-CSF, granulocyte-macrophage colony-stimulating factor \\ G-CSF, granulocyte colony-stimulating factor \\ M-CSF, macrophage colony-stimulating factor \\ MC, mononuclear cell \\ Con A, concanavalin A \\ PMA, phorbol myristate acetate \\ CFU-GM, colony-forming unit-granulocyte-macrophage \\ CSA, colony-stimulating activity \\ EF, elongation factor \\ NK cell, natural killer cell
}

The human neonate is at increased risk of severe infection due to pyogenic bacteria compared with older infants and children (1). A major factor contributing to this increased susceptibility to bacterial infection is the inability of the neonate to produce adequate numbers of mature neutrophils in response to such an infection (2-4). Circulating neutrophil precursors (CFU-GM) are elevated as much as 10 - to 20 -fold in the neonate (5), and neonatal bone marrow also contains increased numbers of neutrophil precursors (6); however, these data do not necessarily indicate an increase in the total body pool of CFU-GM. Although it has not been possible to measure the total body pool of granulocytic precursors in the human, Christensen and Rothstein (7) estimated that 20-d gestation rats, which also have increased circulating CFU-GM, contained only about $10 \%$ as many CFUGM per g of body weight as did adult rats. These workers also have demonstrated that, in infected human neonates, neutropenia accompanied by depletion of the neutrophil storage pool was strongly associated with a fatal outcome, whereas neutropenic patients with normal neutrophil storage pools usually survived (3).

Neutrophil function is also impaired in the human neonate $(8,9)$. Neutrophil chemotaxis is less efficient than that of adult neutrophils under a variety of conditions (10-13). Although granulocytes from healthy neonates ingest and kill bacteria about as well as those from adults under optimal conditions (14-16), when conditions are suboptimal (e.g., limiting concentrations of opsonin) or if neutrophils are obtained from sick neonates, neonatal neutrophils ingest bacteria less avidly than do adult neutrophils (reviewed in 8,17 ).

The CSF are a group of acidic glycoproteins that play an important role in the regulation of the production and function of hematopoietic cells $(18,19)$. These growth factors were initially identified as colony-stimulating activities that were able to sup- 
port the growth of hematopoietic progenitor cells in semisolid media (20). Recently, the genes coding for several of the proteins responsible for these activities have been cloned (reviewed in 18). When incubated with bone marrow, GM-CSF supports the development of colonies containing cells of both granulocyte (neutrophils and eosinophils) and monocyte/macrophage lineages $(21-23)$. GM-CSF also supports the formation of erythroid and megakaryocytic colonies (23). As their names indicate, G-CSF and M-CSF each support the development of colonies primarily restricted to a single lineage $(24,25)$. In addition to these effects on proliferation and differentiation of hematopoietic precursors, the CSF have also been shown to mediate important effects on mature cells as well (18). For example, GM-CSF augments the function of mature neutrophils, macrophages, and eosinophils, including effects on the ingestion and killing of microorganisms, tumoricidal activity, and the production of cytokines (21, 2629).

We hypothesized that the known deficiencies of granulocyte production and function in the newborn could be explained, in part, by reduced production of colony-stimulating factors by neonatal MC. We studied the expression of GM-CSF, G-CSF, and M-CSF mRNA and protein in whole MC, monocyte, and T lymphocyte ( $\mathrm{T}$ cell) preparations. The results suggest that neonatal cells produce less GM-CSF, somewhat more M-CSF, and similar amounts of G-CSF compared with adult cells.

\section{MATERIALS AND METHODS}

Materials. Hanks' balanced salt solution, L-glutamine, FCS, penicillin, and streptomycin were purchased from Gibco, Grand Island, NY. RPMI 1640 containing $25 \mathrm{mM} \mathrm{N} N$-2-hydroxyethylpiperazine- $N^{\prime}$-2-ethanesulfonic acid buffer was obtained from Cellgro, Dulles International Airport, Washington, DC, and contained less than 0.3 endotoxin units lipopolysaccharide $/ \mathrm{mL}$ by limulus amebocyte lysate assay (Pyrotell Associates of Cape Cod, Inc., Woods Hole, MA). Ficoll-Hypaque and Con A were purchased from Pharmacia Fine Chemicals, Piscataway, NJ. PMA and bacterial lipopolysaccharide were obtained from Sigma Chemical Company (St. Louis, MO). NCTC 109 tissue culture media was obtained from M. A. Bioproducts (Walkersville, MD). Ionomycin was obtained from Calbiochem (La Jolla, CA).

Cell preparations. MC were isolated from peripheral blood of healthy adult donors or umbilical cord blood of healthy term neonates by Ficoll-Hypaque density gradient centrifugation as previously described (30), washed twice in Hanks' balanced salt solution, resuspended, and cultured in RPMI 1640 containing 2 $\mathrm{mM}$ L-glutamine, $50 \mathrm{U} / \mathrm{mL}$ penicillin $\mathrm{G}, 50 \mu \mathrm{g} / \mathrm{mL}$ streptomycin (referred to hereafter as medium), and $5 \%$ human $\mathrm{AB}$ serum. Monocytes were isolated from MC by adherence to plastic culture dishes for $2 \mathrm{~h}$, then nonadherent cells were removed by washing eight times in PBS; such monolayers were greater than $90 \%$ monocytes and less than $5 \%$ lymphocytes as described (31). T cells were purified as described (32) by treatment of MC with $\mathrm{T}$ cell Lymphokwik, a cocktail of MAb and complement, as specified by the manufacturer (One Lambda, Los Angeles, CA). The compositions of the $\mathrm{MC}$ and $\mathrm{T}$ cell preparations were assessed by indirect immunofluorescence microscopy and/or immunofluorescent flow cytometry after staining as described (33) with the following MAb: 9.6-CD2 (T and NK cells); 64.1-CD3 (T cells); 2H7-Bp32 (B cells); 5F1-CDW14 (monocytes); 1G10-CDW15 (granulocytes); M21-IgG1 murine myeloma protein (negative control); and Fc1-CD16 (NK cells). MAb 9.6, 64.1, and 2H7 were obtained from Genetic Systems (Seattle, WA); 5F1 and 1 G10 were provided by Dr. I. Bernstein, Fred Hutchinson Cancer Research Center, Seattle, WA. Fcl was provided by Dr. E. Clark, University of Washington. M21 was purchased from Litton Bionetics, Kensington, MD. The compositions of the adult and neonatal preparations were similar: the average composition of the adult MC preparations was $52 \% \mathrm{~T}$ cells, $7 \%$ NK cells, $20 \%$ monocytes, $13 \% \mathrm{~B}$ cells, and $2 \%$ granulocytes and that of the neonatal MC preparations was $49 \%$ T cells, $10 \%$ NK cells, $19 \%$ monocytes, $17 \% \mathrm{~B}$ cells, and $3 \%$ granulocytes. Both adult and neonatal T cell preparations contained $\geq 98 \% \mathrm{CD} 2+$ cells and $\leq 1 \%$ granulocytes, monocytes, or $\mathrm{B}$ cells. On average, adult $\mathrm{T}$ cell preparations contained $92 \% \mathrm{CD} 3+$ cells (T cells) and $9 \%$ $\mathrm{CD} 16+$ cells (NK cells). The average composition of neonatal T cell preparations was similar: $87 \%$ were $\mathrm{CD} 3+(\mathrm{T}$ cells) and $12 \%$ were CD16+ (NK cells).

Cell culture. Blood MC and T cells were cultured in conical 15 -mL polypropylene tubes at $5 \times 10^{6}$ per $\mathrm{mL}$ and stimulated with Con A $(25 \mu \mathrm{g} / \mathrm{mL})$ with or without PMA $(50 \mathrm{ng} / \mathrm{mL})$. Monocytes were cultured in medium containing $20 \% \mathrm{AB}$ serum in tissue culture flasks and stimulated with LPS $(10 \mu \mathrm{g} / \mathrm{mL})$. Supernatants were collected after the indicated interval, frozen at $-70^{\circ} \mathrm{C}$, and later assayed for colony-stimulating activity and for GM-CSF protein by ELISA. Preliminary experiments with MC indicated that maximal CSA and GM-CSF protein levels were detected after $48 \mathrm{~h}$ of stimulation; thus, the data reported in Tables 1 and 2 were generated from studies of supernatants collected at this interval.

RNA isolation and Northern blot analysis. Total cellular RNA was isolated from the cell preparations by the guanidinium isothiocyanate/cesium chloride method and quantitated spectrophotometrically as previously described (34). RNA was electrophoresed in $2.2 \mathrm{M}$ formaldehyde- $1 \%$ agarose gels, transferred to Nytran membranes (Schleicher \& Schuell, Keene, NH), UVirradiated, and baked at $80^{\circ} \mathrm{C}$ for $90 \mathrm{~min}$ as described (35). Blots were hybridized sequentially with ${ }^{32} \mathrm{P}$-labeled RNA probes transcribed from the human cDNA for GM-CSF, G-CSF, and MCSF; these cDNA were provided by Immunex Corp., Seattle, WA. After hybridization, the filters were washed at $63^{\circ} \mathrm{C}$ with 6 $\times$ sodium chloride, sodium citrate (SSC), $0.1 \%$ SDS for $30 \mathrm{~min}$, then with $0.1 \times$ SSC, $0.1 \%$ SDS for $30 \mathrm{~min}$, and autoradiographed at $-80^{\circ} \mathrm{C}$. Nytran filters were then stripped by boiling in $20 \mathrm{mM}$ Tris pH $8.5,2 \mathrm{mM}$ EDTA, and $0.1 \%$ SDS for $15 \mathrm{~min}$, dried, and reprobed. To determine if loading of RNA was similar in each lane, filters subsequently were probed to detect human EF 1- $\alpha$, a housekeeping gene, or were stained with methylene blue to detect the ribosomal RNA bands as described (36). The EF probe (provided by R. M. Perlmutter, University of Washington) was ${ }^{32}$-labeled by the random hexamer method (37).

CSA assays. Bone marrow was aspirated from normal donors, heparinized, and diluted in $5 \mathrm{~mL}$ supplemented NCTC 109 tissue culture medium. The marrow was layered over Ficoll-Hypaque, centrifuged at $400 \times g$ for $30 \mathrm{~min}$ at room temperature, and the cells at the interface zone were removed, washed, and resuspended. Cells were diluted to $1 \times 10^{6}$ nucleated marrow cells/ $\mathrm{mL}$ in supplemented NCTC 109 media containing $10 \%$ FCS and placed in 20-mL aliquots in plastic tissue culture flasks (Corning T-75, Corning NY) in a $37^{\circ} \mathrm{C}, 5 \% \mathrm{CO}_{2}$ incubator for 2 $\mathrm{h}$ to remove monocytes. The nonadherent cells were adjusted to a concentration of $5 \times 10^{6}$ cells $/ \mathrm{mL}$ and incubated with an equal volume of $2 \%$ sheep red blood cells for $15 \mathrm{~min}$ at $37^{\circ} \mathrm{C}$. The cells were pelleted $(400 \times g$ for $5 \mathrm{~min})$ and incubated at $4^{\circ} \mathrm{C}$ for 30 min. The buoyant cells were collected after a second FicollHypaque centrifugation and washed; the T-depleted, phagocytedepleted bone marrow cells were diluted to a concentration of 1 $\times 10^{6}$ cells $/ \mathrm{mL}$.

Final plating suspensions contained $1 \times 10^{5} \mathrm{~T}$-depleted nonadherent bone marrow $\mathrm{MC} / \mathrm{mL}, 20 \% \mathrm{FCS}$, a source of CSA (either $10 \%$ conditioned medium from-phytohemagglutininstimulated MC from adults or $20 \%$ human placental-conditioned medium or the experimental supernatants at $10 \% \mathrm{vol} / \mathrm{vol})$, and $0.3 \%$ agar. Recombinant human G-CSF (sp act $9.4 \times 10^{7} \mathrm{U} / \mathrm{mg}$; Amgen, Inc., Thousand Oaks, CA) and recombinant human GM$\mathrm{CSF}\left(4.1 \times 10^{6} \mathrm{U} / \mathrm{mg}\right.$; Genetics Institute, Cambridge, MA) were used as controls in these assays. Suspensions (1 mL) were placed in 35-mm plastic Petri dishes (Lux; Lab-Tech Division, Miles Laboratories, Naperville, IL), allowed to gel at room temperature, and placed in a $37^{\circ} \mathrm{C}, 5 \% \mathrm{CO}_{2}, 100 \%$ humidity for 7 
Table 1. CSA of adult and neonatal MC supernatants

\begin{tabular}{lcccc}
\hline & $\begin{array}{c}\text { Total colonies } \\
\text { (at 21 d) }\end{array}$ & $\begin{array}{c}\text { \% colonies containing } \\
\text { macrophages }\end{array}$ & $\begin{array}{c}\text { \% colonies containing } \\
\text { eosinophils }\end{array}$ & $\begin{array}{c}\text { colonies containing } \\
\text { granulocytes }\end{array}$ \\
\hline Adult MC supernatants $(n=6)$ & $23 \pm 8 \dagger$ & $46 \pm 11$ & $23 \pm 13$ & $63 \pm 11$ \\
Neonatal MC supernatants $(n=6)$ & $27 \pm 11$ & $72 \pm 19 \ddagger$ & $7 \pm 6 \ddagger$ & $59 \pm 23$ \\
Recombinant GM-CSF $(282 \mathrm{pM})$ & 75 & 18 & 62 & 38 \\
Recombinant G-CSF $(282 \mathrm{pM})$ & 79 & 8 & 0 & 100 \\
\hline
\end{tabular}

* Colonies are reported as colonies per $10^{5}$ marrow MC.

$\dagger$ Mean \pm SD.

$\ddagger p<0.05$ compared with comparable adult supernatants.

Table 2. Secretion of GM-CSF by adult and neonatal blood MC and T cells

\begin{tabular}{lllc}
\hline & \multicolumn{1}{c}{ Cell type } & \multicolumn{1}{c}{ Stimulus } & $\begin{array}{c}\text { GM-CSF } \\
(\mathrm{pg} / \mathrm{mL} \pm \mathrm{SD})\end{array}$ \\
\hline Adult & $\mathrm{MC}(n=7)$ & Con A & $373 \pm 112$ \\
& $\mathrm{MC}(n=3)$ & Con A + PMA & $1053 \pm 185$ \\
& T cells $(n=7)$ & Con A + PMA & $5275 \pm 1962$ \\
Neonatal & MC $(n=7)$ & Con A & $157 \pm 78^{*}$ \\
& MC $(n=3)$ & Con A + PMA & $450 \pm 74 \dagger$ \\
& T cells $(n=7)$ & Con A + PMA & $2577 \pm 1006^{*}$ \\
\hline
\end{tabular}

${ }^{*} p<0.01$ compared with comparable adult preparations.

$\dagger p<0.05$ compared with comparable adult preparations.

or $21 \mathrm{~d}$. All assays were performed in triplicate. Colonies of $>50$ cells were counted using an inverted microscope, and each colony was scored for the morphology of the cell type(s) it contained as previously described (38).

$G M-C S F$ ELISA. GM-CSF protein concentrations in supernatants from adult and cord $M C$ and $T$ cell preparations were determined using a GM-CSF ELISA as specified by the manufacturer (Genzyme Co., Boston, MA). Dilutions of each supernatant were run in duplicate in each assay and the concentration of GM-CSF in each specimen determined by comparison with a standard curve generated by dilutions of recombinant GM-CSF.

Densitometry. The relative intensity of bands on Northern blot autoradiographs was determined using a Visage 60 densitometer with a Sun Microsystems computer (Biolmage, Ann Arbor, MI). Although only a single exposure is shown in the figures, multiple exposures were obtained to ensure that the analysis was performed within the linear range of the film. Values represent the integrated intensity of the band. Results are presented as the ratio of the peak values for cells from neonates to values for cells from adults for a given probe. When total values for all time points were evaluated rather than the peak value, similar results were obtained.

Statistics. Data are expressed as mean \pm 1 SD. Statistical analysis was performed by a two-tailed $t$ test, and comparison groups were considered significantly different if $p<0.05$.

\section{RESULTS}

Accumulation of CSF $m R N A$ by adult and neonatal leukocytes. We initially compared the accumulation of the cognate mRNA for GM-CSF, G-CSF, and M-CSF in paired adult and neonatal MC preparations after stimulation with Con $\mathrm{A}(25 \mu \mathrm{g} / \mathrm{mL})$, as shown by a representative Northern blot (Fig. 1); each lane on the filter contained a similar amount of RNA, as indicated by staining of $28 \mathrm{~S}$ and $18 \mathrm{~S}$ ribosomal RNA bands by methylene blue (not shown). GM-CSF mRNA accumulation by neonatal $\mathrm{MC}$ under these conditions was diminished in each of six experiments (by densitometry, mean $=30 \%$ of adult values; range $=$ $12-54 \%$ ). A striking peak of GM-CSF mRNA accumulation was observed at 4-6 $\mathrm{h}$ in the adult MC but not in neonatal MC. GCSF mRNA accumulation was similar in the adult and neonatal $\mathrm{MC}$, with some variation in kinetics noted between subjects under these conditions. M-CSF mRNA accumulation by neonatal MC was consistently greater than that by adult MC (by

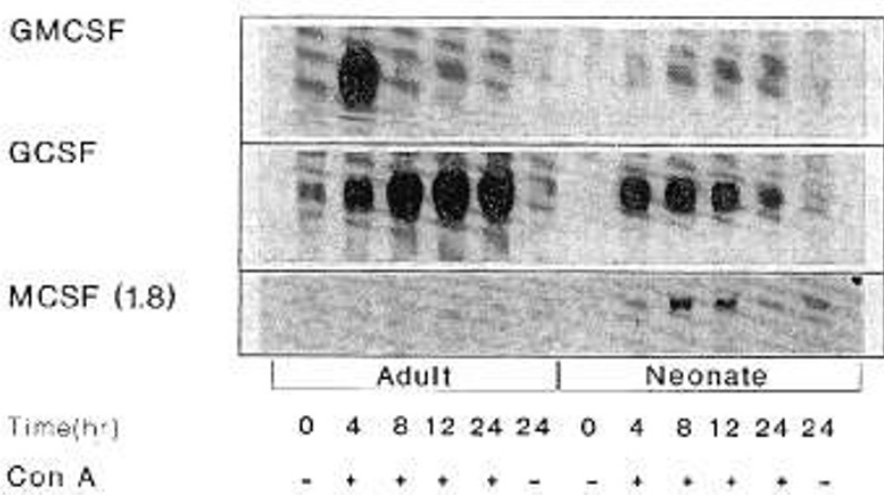

Fig. 1. Northern blot analysis of CSF mRNA accumulation in adult and neonatal blood MC. Cells were cultured for the indicated time with $(+)$ or without (-) Con A stimulation. In each lane, $10 \mu \mathrm{g}$ of total RNA was electrophoresed. Blots were hybridized sequentially with the indicated probes and then autoradiographed. For M-CSF, only an $\sim 1.8 \mathrm{-kb}$ mRNA was detected under these conditions. Loading of RNA was similar in each lane as determined by comparable $28 \mathrm{~S}$ and $18 \mathrm{~S}$ ribosomal RNA bands after staining of filters with methylene blue (not shown).

\section{$E F$}

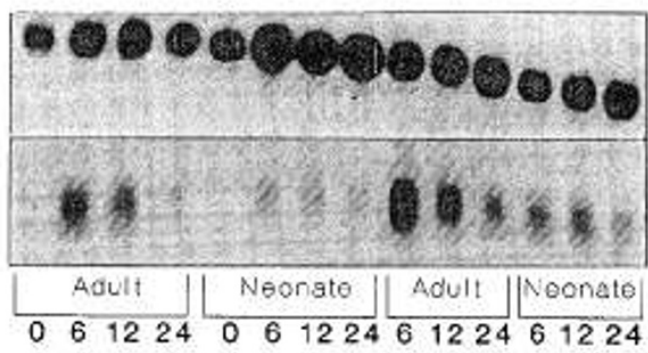

Time $(h r)$

0612240612246122461224

Stimulus

ConA + PMA

Ionomycin + PMA

Fig. 2. Northern blot analysis of CSF accumulation in adult and neonatal $\mathrm{T}$ cells. $\mathrm{T}$ cells were purified and stimulated with Con $\mathrm{A}+$ PMA or ionomycin + PMA for the indicated times. In each lane, $10 \mu \mathrm{g}$ of RNA was electrophoresed. Blots were hybridized sequentially with GM-CSF, G-CSF, and M-CSF probes; no bands were detected with the latter two probes, and they are not shown. Blots were hybridized subsequently with an EF probe to demonstrate loading of RNA.

densitometry, mean $=$ four times adult values; range $=2$ to 7 fold). Qualitatively similar results were obtained when MC were stimulated with Con A + PMA, but the density of the bands was greater.

Similar to the results with $\mathrm{MC}$, when paired T-cell preparations (Fig. 2) from adult and neonatal subjects were stimulated with a combination of Con A $(25 \mu \mathrm{g} / \mathrm{mL})$ and PMA $(50 \mathrm{ng} / \mathrm{mL}), \mathrm{GM}-$ CSF mRNA accumulation by neonatal $\mathrm{T}$ cells was decreased, whereas EF mRNA content was similar (Fig. 2). Overall, GMCSF mRNA accumulation was decreased in five of six neonatal T-cell preparations (by densitometry, mean $=24 \%$ of adult values; range $=11-45 \%$ ); in one pair, adult and neonatal $T$ cells accumulated equivalent amounts of this message. In three additional experiments, neonatal $\mathrm{T}$ cells accumulated approximately 
one third as much GM-CSF mRNA as did adult $\mathrm{T}$ cells after stimulation with ionomycin $(0.5 \mu \mathrm{M})$ plus PMA $(50 \mathrm{ng} / \mathrm{mL})$ (Fig. 2). No accumulation of either G-CSF or M-CSF mRNA was detected in adult or neonatal $\mathrm{T}$ cells with either stimulus (data not shown).

The results with purified $T$ cells suggested that they were not the source of G-CSF mRNA and M-CSF mRNA detected in the whole MC. Monocytes are likely to be the major source of these mRNA. As shown in Figure 3, monocytes accumulated each of the three CSF mRNA when stimulated with LPS $(10 \mu \mathrm{g} / \mathrm{mL})$. For G-CSF mRNA and M-CSF mRNA, results with monocytes paralleled those with whole MC. Taking into account differences in loading suggested by results with the EF probe, neonatal monocytes accumulated similar amounts of GM-CSF mRNA and as much (experiment 2) or more (experiment 1) M-CSF mRNA as did adult monocytes. Interestingly, monocytes stimulated with LPS accumulated M-CSF mRNA of $\sim 4.0$ and $\sim 1.8$ kb (Fig. 2), whereas MC stimulated with Con A accumulated the 1.8-kb mRNA only (Fig. 1). In contrast to the results with whole MC and with $T$ cells, GM-CSF mRNA accumulation by adult and neonatal monocytes was similar. This suggests that $T$ cells are likely to have been the major source of GM-CSF mRNA detected in whole $\mathrm{MC}$, although the conditions of stimulation were different.

CSA assays. Supernatants from adult and neonatal MC stimulated for $48 \mathrm{~h}$ with Con A alone (PMA interferes with the biologic assay) were examined for their ability to stimulate the growth of hematopoietic precursors. As shown in Table 1, the total number of colonies generated by adult and neonatal MC supernatants was similar, but the composition of the colonies differed. Although the number of granulocyte-containing colonies was similar in both groups, neonatal MC supernatants generated significantly $(p<0.05)$ more macrophage-containing colonies and significantly $(p<0.05)$ fewer eosinophil-containing colonies as compared with adult MC supernatants. These data suggested increased M-CSF and diminished GM-CSF in the neonatal MC supernatants because recombinant GM-CSF generates large numbers of eosinophil-containing colonies in this

\section{EF}

GMCSF

GCSF

$\operatorname{MCSF}(4.0)$

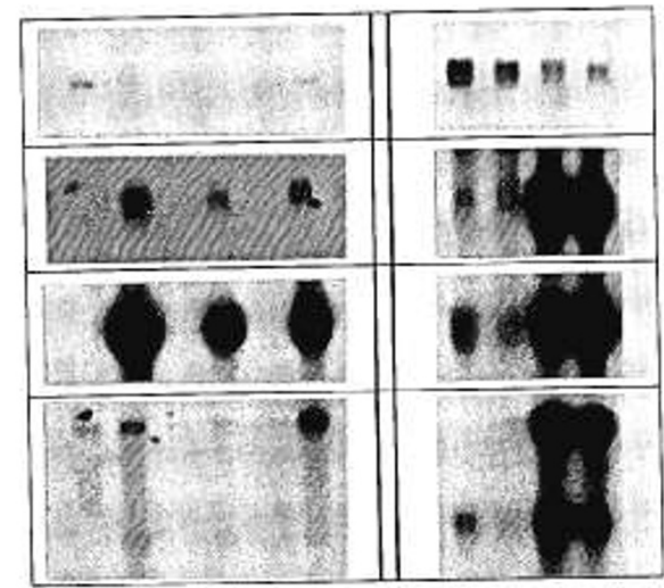

Time (hr)
Amount of
RNA

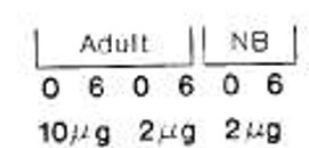

Experiment 1

\section{\begin{tabular}{|llll}
\hline $\mathrm{Ad}$ & NBAd & NB \\
\hline 0 & 0 & 6 & 6
\end{tabular} $5 \mu \mathrm{gg}$}

Experiment 2
Fig. 3. Northern blot analysis of CSF accumulation in adult and neonatal monocytes. Monocytes were purified by adherence and incubated with lipopolysaccharide for 0 to $6 \mathrm{~h}$. Two experiments are shown, and the amounts of RNA electrophoresed in each lane are indicated. Blots were hybridized sequentially with the indicated CSF probes; they were hybridized subsequently with an EF probe to demonstrate loading of RNA. assay. To confirm that GM-CSF was the principal factor contributing to the generation of eosinophil-containing colonies in these assays, we incubated aliquots of the adult and neonatal MC supernatants with an MAb to GM-CSF (39) before incubation with the bone marrow cells. This preincubation blocked the formation of $\sim 80 \%$ of the eosinophil-containing colonies by adult supernatants and $100 \%$ of the eosinophil-containing colonies generated by neonatal supernatants (data not shown). As expected, colonies containing the other cell types were less completely inhibited by preincubation of supernatants with this antibody. In adult and neonatal supernatants, neutrophil-containing colonies were inhibited by 20 and $40 \%$ and monocyte/ macrophage containing colonies were inhibited by 60 and $75 \%$, respectively.

GM-CSF protein determinations. To confirm the differences in GM-CSF observed in the Northern analyses and CSA assays, supernatants from adult and neonatal MC and T cell preparations were collected after stimulation with either Con $\mathrm{A}$ alone or Con A plus PMA and assayed for GM-CSF protein by sandwich ELISA. Preliminary experiments revealed that maximum levels of GM-CSF were detected 24-48 h after stimulation, so we compared the concentrations of GM-CSF in adult and neonatal cell supernatants after this interval. As shown in Table 2, adult MC and T cells secreted significantly $(p<0.01)$ more GM-CSF protein than did neonatal MC and T cells. Neonatal MC stimulated with Con A secreted $42 \%$ as much GM-CSF as adult MC, while neonatal T cells stimulated with Con A plus PMA secreted $48 \%$ as much GM-CSF as adult T cells.

\section{DISCUSSION}

Our data indicate that neonatal MC, compared with adult MC, produced less than $50 \%$ as much GM-CSF as determined by colony-stimulating assays, ELISA, and RNA blot analysis. Diminished GM-CSF production by MC appeared to reflect decreased production by neonatal $T$ cells. Neonatal $T$ cells produced $\sim 25-50 \%$ as much GM-CSF mRNA and protein as did adult $\mathrm{T}$ cells, whereas neonatal and adult monocytes produced similar amounts of GM-CSF mRNA. In contrast to GMCSF, neonatal MC produced on average 4-fold more M-CSF mRNA and supernatants of neonatal MC contained increased M-CSA compared to adult cells. G-CSF mRNA accumulation and G-CSA secretion by neonatal MC and monocytes was comparable to that of adult cells. T cells did not produce detectable M-CSF or G-CSF as determined by RNA blot analysis, consistent with previous reports (reviewed in 18, 19).

These data provide further evidence of the immaturity of certain aspects of neonatal $\mathrm{T}$ lymphocyte function. Along with the diminished GM-CSF production shown in this report, neonatal $T$ cells have an even greater impairment in the production of interferon- $\gamma(32,40,41)$ and IL-4 (42) compared with adult $\mathrm{T}$ cells. This immaturity in lymphokine production is at least in part selective, inasmuch as IL-2 $(32,43)$ and lymphotoxin $(33)$ are produced in normal or increased amounts by neonatal $T$ cells in vitro. Although these in vitro data cannot be assumed to reflect fully the in vivo production of cytokines by healthy or infected neonates, they suggest that reduced production of certain $T$ cell-derived lymphokines may play a role in the increased susceptibility of neonates to infection. Unlike neonatal T cells, we found that neonatal monocytes produced as much GM-CSF, G-CSF, and M-CSF mRNA as adult monocytes. In other studies, the production of the cytokines IL-1 and tumor necrosis factor by monocytes isolated from healthy term neonates has also been equivalent to that of adult monocytes $(31,44,45)$. Thus, in contrast to $T$ cells, diminished production of cytokines by monocytes is less likely to be a factor in the susceptibility of neonates to severe infection.

During fetal and neonatal life, circulating CFU-GM are present in numbers that exceed those in adult blood by $\geq 10$-fold in humans and in rats $(5,7,46-48)$. The rate of proliferation of 
these circulating CFU-GM in vivo is nearly maximal $(5,48)$. In addition, an increased fraction of the colonies derived from neonatal blood (when crude mixtures of CSF are used to support their growth in vitro) is composed of monocyte/macrophages (5, 49), which parallels the relative predominance of M-CSF activity and mRNA produced by neonatal $\mathrm{MC}$ and monocytes in our assays. The high rate of spontaneous proliferation of CFU-GM in neonates may be due in part to increased concentrations of CSA in the blood of neonates compared with adults $(48,50)$. The source of the circulating CSA is unknown. Some of this CSA is due to increased G-CSF and GM-CSF, also suggesting that monocytes may be one source. The presence of increased circulating GM-CSA suggests that the diminished capacity of neonatal T cells to produce GM-CSF is not likely to be a limiting factor in neonatal neutrophil production and release under normal conditions. It is possible that the diminished capacity of neonatal $\mathrm{T}$ cells to produce GM-CSF could be a factor, along with the near-maximal spontaneous rate of CFU-GM proliferation $(5,51)$ and the potentially diminished total body pool of CFU-GM (7), acting to limit the neonate's neutrophil production in response to infection. However, the relative importance of $T$ cells (compared with monocytes or stromal cells) as a source of GM-CSF production in vivo remains unclear and may vary with the clinical situation.

The decreased production of GM-CSF by neonatal $T$ cells could also contribute to the impaired function of neonatal granulocytes. Recombinant GM-CSF has been shown to enhance many functions of human neonatal neutrophils $(52,53)$, including locomotion, chemotaxis, and oxidative responses. Deficiencies in the production of certain lymphokines by neonatal T cells have been implicated in the increased susceptibility of the neonate to infection. In particular, the striking reduction in interferon- $\gamma$ production by neonates is likely to contribute to the increased risk of neonatal infection with intracellular pathogens such as the herpesviruses, Toxoplasma, and Listeria (40). The modestly diminished production of GM-CSF by neonatal T cells that we observed was statistically significant, but it is unclear if this difference is biologically important. Studies of the in vivo production of GM-CSF may be required to address this possibility.

Acknowledgments. The authors thank S. Gills for CSF probes, R. M. Perlmutter for the Elongation Factor probe, W. M. Weaver for technical assistance, and B. Lovseth for assistance in manuscript preparation.

\section{REFERENCES}

1. Siegel JD, McCracken GH 1981 Sepsis neonatorum. N Engl J Med 304:642647

2. Manroe BL, Weinberg AG, Rosenfeld CR, Browne R 1979 The neonatal blood count in health and disease. I. Reference values for neutrophilic cells. J Pediatr 95:89-98

3. Christensen RD, Rothstein G 1980 Exhaustion of mature marrow neutrophils in neonates with sepsis. J Pediatr 96:316-318

4. Wilson CB 1990 Developmental immunology and role of host defenses in neonatal susceptibility. In: Remington JS, Klein JO (eds) Infectious Diseases of the Fetus and Newborn Infant, 3rd Ed, WB Saunders, Philadelphia, pp $17-67$

5. Christensen RD, Harper TE, Rothstein G 1986 Granulocyte-macrophage progenitor cells in term and preterm neonates. J Pediatr 109:1047-1051

6. Shapiro LM, Bassen FA 1941 Sternal marrow changes during the first week of life. Correlation of peripheral blood findings. Am J Med Sci 292:341-354

7. Christensen RD, Rothstein G 1984 Pre- and postnatal development of granulocytic stem cells in the rat. Pediatr Res 18:599-602

8. Hill HR 1987 Biochemical, structural, and functional abnormalities of polymorphonuclear leukocytes in the neonate. Pediatr Res 22:375-382

9. Cairo MS 1989 Neonatal neutrophil host defense. Am J Dis Child 143:40-46

10. Miller ME 1971 Chemotactic function in the human neonate: humoral and cellular aspects. Pediatr Res 5:487-492

11. Klein RB, Fischer TJ, Gard SE, Biberstein BS, Rich KC, Stiehm ER 1977 Decreased mononuclear and polymorphonuclear chemotaxis in human newborns, infants and young children. J Pediatr 60:467-472

12. Anderson DC, Hughes BJ, Smith CW 1981 Abnormal mobility of neonatal polymorphonuclear leukocytes. J Clin Invest 68:863-874

13. Bone A, Zeligs BJ, Bellanti JA 1982 Chemotactic responses of various differ- entiational stages of neutrophils from human cord and adult blood. Infect Immun 35:921-928

14. Gluck L, Silverman WA 1957 Phagocytosis in premature infants. Pediatrics 20:951-957

15. McCracken GH, Eichewald HF 1971 Leukocyte function and the development of opsonic and complement activity in the neonate. Am J Dis Child 121:120126

16. Harris MC, Stroobant J, Cody CS, Douglas SD, Polin RA 1983 Phagocytosis of group B streptococcus by neutrophils from newborn infants. Pediatr Res 17:358-361

17. Miller ME 1979 Phagocyte function in the neonate: selected aspects. Pediatrics 64:709-712

18. Clark SC, Kamen R 1987 The human hematopoietic colony-stimulating factors. Science 236:1229-1237

19. Groopman JE, Molina JM, Scadden DT 1989 Hematopoietic growth factors: biology and clinical applications. N Engl J Med 321:1449-1459

20. Sachs L 1987 The molecular control of blood cell development. Science 238:1374-1379

21. Metcalf D 1986 The molecular biology and functions of the granulocytemacrophage colony-stimulating factors. Blood 67:257-267

22. Metcalf D, Begley CF, Johnson GR, Nicola MA, Vadas MA, Lopez AF Williamson DJ, Wong GG, Clark SC, Wang EA 1986 Biologic properties in vitro of a recombinant human granulocyte-macrophage colony-stimulating factor. Blood 67:37-45

23. Sieff CA, Emerson SG, Donahue RE, Nathan DG, Wang EA, Wong GG, Clark SC 1985 Human recombinant granulocyte-macrophage colony-stimulating factor: a multilineage hematopoietin. Science 230:1171-1173

24. Nagata S, Tsuchiya M, Asano S, Kaziro Y, Yamazaki T, Yamamoto O, Hirata Y, Kubota N, Oheda M, Nomura H, Ono M 1986 Molecular cloning and expression of cDNA for human granulocyte colony-stimulating factor. Nature 319:415-418

25. Kawasaki ES, Ladner MB, Wang AM, Arsdell JV, Warren MK, Coyne MY, Schweickart VL, Lee MT, Wilson JK, Boosman A, Stanley ER, Ralph P, Mark DF 1985 Molecular cloning of a complementary DNA encoding human macrophage-specific colony-stimulating factor (CSF-1). Science 230:291-296

26. Weisbart RH, Golde DW, Clark SC, Wong GG, Gasson JC 1985 Human granulocyte-macrophage colony-stimulating factor is a neutrophil activator. Nature 314:361-363

27. Lopez AF, Williamson DJ, Gamble JR, Begley CG, Harlan JM, Klebanoff SJ Waltersdorph A, Wong G, Clark SC, Vadas MA 1986 Recombinant human granulocyte-macrophage colony-stimulating factor stimulates in vitro mature human neutrophil and eosinophil function, surface receptor expression, and survival. J Clin Invest 78:1220-1228

28. Fleischmann J, Golde DW, Weisbart RH, Gasson JC 1986 Granulocytemacrophage colony-stimulating factor enhances phagocytosis of bacteria by human neutrophils. Blood 68:708-711

29. Weisbart RH, Golde DW, Gasson JC 1987 Human GM-CSF primes neutrophils for enhanced oxidative metabolism in response to the major physiological chemoattractants. Blood 69:18-21

30. Wilson CB, Remington JS 1979 Effects of monocytes from human neonates on lymphocyte transformation. Clin Exp Immunol 36:511-520

31. Burchett SK, Weaver WM, Westall JW, Larsen A, Kronheim S, Wilson CB 1988 Regulation of tumor necrosis factor/cachectin and interleukin 1 secretion in human mononuclear phagocytes. J Immunol 140:3473-3481

32. Wilson CB, Westall J, Johnston L, Lewis DB, Dower SK, Alpert AR 1986 Decreased production of interferon-gamma by human neonatal cells. J Clin Invest 77:860-867

33. English BK, Burchett SK, English JD, Ammann AJ, Wara DW, Wilson CB 1988 Production of lymphotoxin and tumor necrosis factor by human neonatal mononuclear cells. Pediatr Res 24:717-722

34. Lewis DB, Larsen A, Wilson CB 1986 Reduced interferon-gamma mRNA levels in human neonates. J Exp Med 163:1018-1023

35. Maniatis T, Fritsch EF, Sambrook J 1982 Extraction, purification and analysis of mRNA from eukaryotic cells. In: Molecular Cloning: A Laboratory Manual. Cold Spring Harbor Laboratory Press, Cold Spring Harbor, NY, p 187

36. Herrin DL, Schmidt GW 1988 Rapid reversible staining of Northern blots prior to hybridization. Biotechniques 6:196-197

37. Feinberg AP, Vogelstein B 1983 A technique for radiolabeling DNA restriction endonuclease fragments to high specific activity. Anal Biochem 132:6-13

38. Hammond WP, Miller JE, Starkebaum G, Zweerink HJ, Rosenthal AS, Dale DC 1988 Suppression of in vitro granulocytopoiesis by captopril and penicillamine. Exp Hematol 16:674-680

39. Brown CB, Hart CE, Cortin DM, Bailey MC, Kaushansky K 1990 Two neutralizing monoclonal antibodies against human granulocyte-macrophage colony-stimulating factor recognize the receptor binding domain of the molecule. J Immunol 144:2184-2189

40. Wilson CB, Lewis DB 1990 Basis and implications of selectively diminished cytokine production in neonatal susceptibility to infection. Rev Infect Dis 12:S410-S420

41. Bryson YJ, Winter HS, Gard SE, Fischer TJ, Stiehm ER 1980 Deficiency of immune interferon production by leukocytes of normal newborns. Cell Immunol 55:191-200

42. Lewis DB, Yu CC, Meyer J, English BK, Kahn SJ, Wilson CB 1991 Cellular and molecular mechanisms for reduced interleukin-4 and interferon-gamma production by neonatal $T$ cells. J Clin Invest 87:194-202 
43. Hayward AR, Kurnick J 1981 Newborn T cell suppression: early appearance, maintenance in culture, and lack of growth factor suppression. J Immunol 126:50-53

44. Dinarello CA 1985 An update on interleukin-1; from molecular biology to clinical relevance. J Clin Immunol 5:287-297

45. Weatherstone KB, Rich EA 1989 Tumor necrosis factor/cachectin and interleukin-1 secretion by cord blood monocytes from premature and term neonates. Pediatr Res 25:342-346

46. Knudtzon S 1974 In vitro growth of granulocytic colonies from circulating cells in human cord blood: Blood 43:357-361

47. Liang DC, Ma SW, Lin-Chu M, Lan CC 1988 Granulocyte/macrophage colony-forming units from cord blood of premature and full-term neonates: its role in ontogeny of human hemopoiesis. Pediatr Res 24:701-702

48. Laver J, Duncan E, Abboud M, Gasparetto C, Sahdev I, Warren D, Bussel J, Auld P, O'Reilly RJ, Moore MAS 1990 High levels of granulocyte and granulocyte-macrophage colony-stimulating factors in cord blood of normal full-term neonates. J Pediatr 1 16:627-632

49. Ijima H, Suda T, Miura Y 1982 Predominance of macrophage-colony formation in human cord blood. Exp Hematol 10:234-240

50. Barak Y, Blachar Y, Levin S 1980 Neonatal neutrophilia: possible role of humoral granulopoietic factor. Pediatr Res 14:1026-1028

51. Christensen RD, Hill HR, Rothstein G 1983 Granulocytic stem cell (CFUc) proliferation in experimental group B streptococcal sepsis. Pediatr Res 17:278-280

52. Frenck Jr RW, Buescher ES, Vadhan-Raj S 1989 The effects of recombinant human granulocyte-macrophage colony stimulating factor on in vitro cord blood granulocyte function. Pediatr Res 26:43-48

53. Cairo MC, van deVen C, Toy C, Mauss D, Sender L 1989 Recombinant human granulocyte-macrophage colony-stimulating factor primes neonatal granulocytes for enhanced oxidative metabolism and chemotaxis... Pediatr Res 26:395-399 